\title{
IMPACT ANALYSIS OF COOPERATIVE LEARNING MODEL APPLICATION TyPE Two STAY Two STRAy (TSTS) TOWARD LEARNING OUTCOMES OF MATHEMATICS
}

\author{
Muhammad Nurhusain ${ }^{1)}$ \\ 1)Program Studi Pendidikan Matematika, STKIP YPUP Makassar, Makassar, Indonesia \\ E-mail: zein.alhusain@gmail.com
}

\begin{abstract}
This research is a comparative experiment. This study aims to determine the effect of the application of cooperative learning model Two Stay Two Stray (TSTS) towards mathematics learning outcomes through comparison with the results of studying mathematics taught using direct learning model. Population, namely the eighth grade students of SMP Negeri 2 Polong Bangkeng Utara Kabupaten Takalar semester of academic year 2016/2017, with a sample of students in grade VIIIA and VIIIB class. The data were analyzed using descriptive statistical analysis techniques and inferential statistics. Descriptive analysis showed that the average student learning outcomes experimental class at the high category, an average of 80.78 with a standard deviation of 11.28; and the average student learning outcomes control class in middle category with an average score of 73.82 with a standard deviation of 12.98. Inferential analysis results obtained H0 and H1 accepted. It can be concluded with $95 \%$ confidence that the results of students 'mathematics learning through cooperative learning model Two Stay Two Stray (TSTS) higher than the results of students' mathematics learning through direct learning model.
\end{abstract}

Keywords: Cooperative, Two Stay Two Stray (TSTS), Learning Outcomes

\section{INTRODUCTION}

The development of science and technology (Science and Technology) enables all parties can obtain abundant information, quickly and easily from a variety of sources and places in the world. Thus, students need to have the ability to obtain, select, manage, survive on the state information that is always changing, uncertain and competitive. So it takes a variety of method and learning strategy that accelerate knowledge acquisition. Due to the development of science and technology requires critical thinking, systematic, logical, creative, and effective cooperation willingness.

Mathematics is one of the basic science that has a strong and clear structure and link with the concept. The function and role of mathematics makes it easy to keep abreast of the times, namely science and technology. Math becomes a means of logical, creative, systematic, and critical thinking.
Because of the importance of mathematics in various levels of education, it is necessary to get the attention and serious treatment, the students in various levels of education, including the middle school is absolutely required to master math and expected to have a high result.

To make the potential above happen, a new orientation is required in math education that includes the reformation of math education program target towards the development of thinking and speaking ability, preparing the students to face the social issue of the impact of science and technology, cultivation of ethical values and aesthetics, problem-solving skills, development of attitude independence, creativity and responsibility.

To achieve the maximum educational purposes is not only the factor of students but also the factor of teacher. In preparing a learning material to the stage of implementation, a teacher must be highly selective in choosing the model and learning 
approach that will be applied. Selecting of models, approaches and methods in accordance with the characteristics of the material to be taught is an important factor to achieve an effective learning process and quality learning outcomes. The learning outcomes is in accordance proposed by A. J. Romizowski that the learning outcomes is output of a processing system input. Input from the system is in the form of a variety of information while the output is an act or performance. Learning outcomes are patterns of actions, values, understandings, attitudes, appreciation and skills (Suprijono, 2009).

The fact is not always in line with expectation. Based on the previous research obtained by researcher from the teachers of math, the mathematics learning outcomes at the eighth grade of SMP Negeri 2 Polong Bangkeng Utara, Takalar Regency is still low. The cause is largely due to the lack of student participation in the learning process. This happens because the study only focused on teachers. From interviews with teachers of mathematics, that the learning model used in SMP Negeri 2 Polong Bangkeng Utara, Takalar Regency is still rely on direct learning. Direct instruction is often used because the teacher thought it was easy to implement in learning process. However, it can not be denied that in the direct instruction which known as active teaching. Direct learning also called whole-class teaching. It refers to a style of teaching where teachers are actively involved in carrying directly on the entire class where there is a phenomenon in direct learning has focused on teacher (Suprijono, 2009).

To overcome the disadvantages of learning, should be select the appropriate learning method so that the learning objectives can be achieved and students were able to involve themselves actively. One of the learning model that can be used in mathematics learning is cooperative learning model Two Stay Two Stray (TSTS).

Cooperative learning model Two Stay Two Stray (TSTS) was developed based on the Spencer Kagan premise (1992). The Two Stay Two Stray learning model is provide an opportunity to share results and information with other groups (Lie, 2007). The Two Stay Two Stray learning model is two students stay in group and two other students visit another group. Two students who stay in group provide information to guests about the group's result, while the guests record the results of the group discussion which visited by them (Shoimin, 2014). According to Nurhusain (2013) that the cooperative learning type Two Stay Two Stray (TSTS) can improve students' mathematics learning outcomes.

Based on the description above, the researcher is interested and motivated to carry out the research that aims to determine the effect of the application of cooperative learning model Two Stay Two Stray (TSTS) towards mathematics learning outcomes through the comparison with the results of studying mathematics taught using direct learning model.

\section{METHODS}

\section{A. Types of research}

The research was an experimental research which involved two classes or two groups, one class as an experimental class and one class as a control class. Experimental class taught by cooperative learning type Two Stay Two Stray (TSTS), while the control class taught by direct learning model.

\section{B. Time and Place of Research}

The research was conducted in the first semester of 2016/2017 academic year in the eighth grade of SMP Negeri 2 Polong Bangkeng Utara which is located in the Lassang Village, Polong Bangkeng Utara, Takalar.

\section{Research Design}

The design used in this research is randommized subjects posttest only control group design Sukardi (2014: 185) with two different treatment groups. Both groups will be randomized to determine the experimental class and control class. The first group as an experimental class taught using cooperative learning model type of two stay two stray (TSTS), while the second group as the control class taught using direct learning model. Once treated, the two groups were given test to determine the effect of treatment given. The study design can be seen in Table I below. 
TABLE I

RESEARCH DESIGN

\begin{tabular}{cccc}
\hline \multicolumn{4}{c}{ RESEARCH DESIGN } \\
\hline Random & Group & Teatment & Post Test \\
\hline $\mathrm{R}$ & $\mathrm{E}$ & $\mathrm{T}_{1}$ & $\mathrm{Y}_{1}$ \\
$\mathrm{R}$ & $\mathrm{K}$ & $\mathrm{T}_{2}$ & $\mathrm{Y}_{2}$ \\
\hline & & Source: Sukardi (2014: 185)
\end{tabular}

$\mathrm{R}$ : Random

E : Experimental class

$\mathrm{K}$ : Control class

$\mathrm{T}_{1}$ : Treatment using cooperative learning model type Two Stay Two Stray (TSTS).

$\mathrm{T}_{2}$ : Treatment using direct learning model

$\mathrm{Y}_{1}$ : The results of students' mathematics learning after being taught by using cooperative learning model type Two Stay Two Stray (TSTS).

$\mathrm{Y}_{2}$ : The results of students' mathematics learning after being taught by using direct learning model.

\section{Population}

The population in this research were all students at the eighth grade of SMP Negeri 2 Polong Bangkeng Utara consisted of 5 classes homogeneous with the number of 122 students, where class $\mathrm{VIII}_{\mathrm{A}}$ consisted of 28 students, class VIII $_{B}$ consisted of 28 students, class VIII $_{C}$ consisted of 24 students, class VIIID consisted of 26 students and class $\mathrm{VIII}_{\mathrm{E}}$ consisted of 16 students in the first semester of 2016/2017 academic year. The population is homogeneous because the students are not classified in a particular grade.

\section{E. Sample}

The sampling technique used was cluster random sampling or random sampling group because the population consisted of several groups/ classes in the eighth grade which have the same average value for each class before giving the treatment. The selected sample is class VIII $_{\mathrm{A}}$ and class $\mathrm{VIII}_{\mathrm{B}}$.

\section{F. Draft of Treatment}

The treatment by applying cooperative learning model Two Stay Two Stray (TSTS) as follows: (a) The teacher divides the students in the group that consists of 4 (four) students; (b) The teacher gives the task in the form of questions that should be discuss; (c) After intra-group discussion is over, two students visit another group; (d) Members of the group who stay in group provide information to guests about the group's result; (e) Two students were served as guests are required to visit each group; (f) If they have done their duties, they returned to their group; (g) the students who visit and those who served a guests match and discuss the work they have done.

The treatment by applying direct learning model as follows: (a) The teacher explains the competencies and learning objectives, lesson background information, the importance of learning, and preparing students to learn; (b) The teacher demonstrates knowledge/ skills or present the information step by step; (c) The teacher plans and provides the early guidance; (d) The teacher checks whether the student has successfully done a task or not and providing feedback; (e) The teacher prepares the advanced training with particular attention for more complex situation in everyday life.

\section{G. Data, Instrument and Data Collection Technique}

The data, source, instrument, and data collection technique in this research are listed in Table II below.

TABLE II

DATA, INSTRUMENT AND DATA COLLECTION TECHNIQUE

\begin{tabular}{llll}
\hline No. & \multicolumn{1}{c}{ Data } & Instrument & \multicolumn{1}{c}{$\begin{array}{c}\text { Data Collection } \\
\text { Technique }\end{array}$} \\
\hline 1. & $\begin{array}{l}\text { The learning } \\
\text { result of } \\
\text { experimental } \\
\text { class } \\
\text { The learning } \\
\text { result of control } \\
\text { class }\end{array}$ & Test & $\begin{array}{l}\text { Providing test at the end } \\
\text { of treatment in } \\
\text { experimental class }\end{array}$ \\
2. Test & & $\begin{array}{l}\text { Providing test at the end } \\
\text { of treatment in control } \\
\text { class }\end{array}$ \\
\hline
\end{tabular}

\section{H. Data Analysis Technique}

\section{Descriptive Statistics}

Descriptive statistics is used to describe the mathematics learning outcomes which obtained from tests of student learning outcomes and student activity during the learning process. For the purpose of analysis, it used table of frequency distribution, average, standard deviation, median, mode, range and the ideal score. The guideline 
used is the procedures adopted from the Education Ministry in 2006 according to the Table III below.

TABLE III STUDENT RESULT CATEGORY

\begin{tabular}{cc}
\hline Score $(\%)$ & Student Result Category \\
\hline $0-54$ & Very Poor \\
$55-64$ & Poor \\
$65-79$ & Average \\
$80-89$ & Good \\
$90-100$ & Very Good
\end{tabular}

Adapted from Education Ministry in 2006

\section{Inferential Statistics}

\section{Normality tests}

Normality test is used to determine whether the data that used is normal distribution or not. For the test used Chi-squared formula which stated as follows:

$$
\chi^{2}=\sum \frac{\left(f_{o}-f_{e}\right)^{2}}{f_{e}}
$$

(Misbahuddin and Hasan. 2013: 279-280)

$\chi^{2}=$ Chi-sqared test

$f_{o}=$ the observed frequency

$f_{e}=$ the expected frequency

The criteria of normal distribution is if $\chi_{\text {test }}^{2}<$ $\chi_{\text {table }}^{2}$ where $\chi_{\text {table }}^{2}$ which gained from $\chi^{2}$ with $\mathrm{df}$ $=(\mathrm{k}-2)$ and the signifcance level $\alpha=0.05$. So, the data is normally distributed. $\chi^{2}{ }_{\text {tabel }}=$ $\chi_{(\alpha ; d k)}^{2}$.

\section{Homogeneity tests}

Homogeneity test is a prerequisite test of analysis on the feasibility of data to be analyzed by using a specific statistical test.

Homogeneity test is used to test the homogeneity data result of learning outcomes with the following formula:

$$
F_{0}=\frac{\text { large variance }}{\text { small variance }}
$$

The criteria of testing if $F_{\text {test }}<F_{\text {table }}$ in the significance level $\propto=0,05$ so, the data is homogeneous. $F_{\text {tabel }}=F_{(x)\left(V_{1}, V_{2}\right)}$, where $V_{1}=$ $n_{1}-1$ and $V_{2}=n_{2}-1$

\section{Hyphotesis Tests}

Statistical analysis to test the hypothesis is "The average of students' mathematics learning outcomes by applying cooperative learning model
Two Stay Two Stray (TSTS) is higher than before applying direct learning model". It was used t-test of independent samples, with formula as follows:

$$
\begin{gathered}
t_{\text {hit }}=\frac{\bar{x}_{1}-\bar{x}_{2}}{s \sqrt{\frac{1}{n_{1}}+\frac{1}{n_{2}}}} \\
\text { Where, } S^{2}=\frac{\left(n_{1}-1\right) S_{1}{ }^{2}+\left(n_{2}-1\right) S_{2}{ }^{2}}{n_{1}+n_{2}-2} \\
\sqrt{\frac{\left(n_{1}-1\right) S_{1}{ }^{2}+\left(n_{2}-1\right) S_{2}{ }^{2}}{n_{1}+n_{2}-2}}
\end{gathered}
$$

(Tiro, 2008: 252)

$S^{2}=$ Combined variance

$S=$ Combined standard deviation

$\bar{x}_{1}=$ Mean of Two Stay Two Stray (TSTS) group

$\bar{x}_{2}=$ Mean of Direct instructional group

$n_{1}=$ The number of Two Stay Two Stray (TSTS) group members.

$n_{2}=$ The number of Direct instructional group members.

$S_{1}=$ Standard deviation of experimental group

$s_{2}=$ Standard deviation of control group

For the hyphothesis testing, The null hyphothesis $H_{0}$ is accepted if $t \leq t_{(1-\alpha)}$ and $H_{0}$ is rejected if $t>t_{(1-\alpha)}$ with the significance level $(\alpha)=0,05$ and degree of freedom $(\mathrm{df})=\mathrm{n}_{1}+\mathrm{n}_{2}-$ 2.

\section{Statistical Hyphothesis}

Statistical hyphothesis used as follows:

$$
\begin{aligned}
& H_{0}: \mu_{2} \leq \mu_{1} \\
& H_{1}: \mu_{2}>\mu_{1}
\end{aligned}
$$

$\mu_{1}=$ the mean score of students' learning outcomes by applying cooperative learning model Two Stay Two Stray (TSTS).

$\mu_{2}=$ the mean score of students' learning outcomes by applying direct learning model.

\section{RESULTS AND DISCUSSION}

\section{A. Research Result}

\section{The Results of Descriptive Statistics Analysis}

Descriptive statistics were used to describe the research variables obtained by the measurement 
results, i.e. the data result of learning algebra factorization rate for each group. The data of test results for experimental class that was taught through cooperative learning model Two Stay Two Stray (TSTS) can be seen in Table IV below:

TABLE IV

DESCRIPTION OF STUDENT LEARNING OUTCOMES SCORES IN EXPERIMENTAL CLASS

\begin{tabular}{cc}
\hline Statistics & Value \\
\hline Sample & 28 \\
Maximum Score & 96 \\
Minimum Score & 50 \\
Range & 46 \\
Mean Score & 80,75 \\
Variance & 126,269 \\
Standard deviation & 11,237 \\
Median & 81,50 \\
Mode & 82 \\
\hline
\end{tabular}

Source: SPSS

The overall score obtained from the respondents, if were grouped in five categories according to the guidelines that were used to follow the procedures applied by the Education Ministry in 2006, then the frequency distribution, percentage and category of learning outcomes on Algebra Factorization at the eighth grade students of SMP Negeri 2 Polong Bangkeng Utara by applying cooperative learning model Two Stay Two Stray (TSTS) can be seen in Table V below:

TABLE V

DISTRIBUTION OF FREQUENCY AND PERCENTAGE IN EXPERIMENTAL CLASS

\begin{tabular}{cccc}
\hline Scores & Category & Frequency & $\begin{array}{c}\text { Percentage } \\
(\boldsymbol{\%})\end{array}$ \\
\hline $0-54$ & Very Poor & 1 & 3,57 \\
$55-64$ & Poor & 1 & 3,57 \\
$65-79$ & Average & 10 & 35,71 \\
$80-89$ & Good & 8 & 28,57 \\
$90-100$ & Very Good & 8 & 28,57 \\
\hline \multicolumn{2}{c}{ Total } & 28 & 100 \\
\hline
\end{tabular}

Based on Table $\mathrm{V}$ above, from 28 students who were given the test, the results on Algebra Factorization shows that the mean score of students' learning outcomes through cooperative learning model Two Stay Two Stray (TSTS) is 80.75 which indicates that the students' ability in understanding the material of Algebra Factorization centered at 80.75 with a standard deviation of 11.273, which means deviation data from the average value is 11.273. Median 81 means $50 \%$ of the students have a score on 81 and
$50 \%$ have a score under 76 . Mode of 82 which means the most students got 82 . Because the value of mean < median < mode value, then shaped of distribution is a negative curve means the tendency of data gathered above the average. Furthermore, based on Table 4 and Table 5, the information is obtained that the average of learning outcomes is 80.75 of the score ideal of 100 and in a good category.

While the data of test results for control class that was taught by applying direct learning model can be seen in Table VI below:

TABLE VI

DESCRIPTION OF STUDENT LEARNING OUTCOMES SCORES IN CONTROL CLASS

\begin{tabular}{cc}
\hline Statistics & Value \\
\hline Sample & 28 \\
Maximum Score & 94 \\
Minimum Score & 45 \\
Range & 49 \\
Mean Score & 73,82 \\
Variance & 168,522 \\
Standard deviation & 12,982 \\
Median & 76 \\
Mode & 70 \\
\hline
\end{tabular}

Source: SPSS

The overall score obtained from the respondents, if were grouped in five categories according to the guidelines that were used to follow the procedures applied by the Education Ministry in 2006, then the frequency distribution, percentage and category of learning outcomes on Algebra Factorization at the eighth grade students of SMP Negeri 2 Polong Bangkeng Utara by applying direct learning model shown in Table VII below:

TABEL VII

DISTRIBUTION OF FREQUENCY AND PERCENTAGE OF DIRECT LEARNING MODEL

\begin{tabular}{|c|c|c|c|}
\hline Score & Category & Frequency & $\begin{array}{c}\text { Percentage } \\
(\%)\end{array}$ \\
\hline $0-54$ & Very Poor & 3 & 10,71 \\
\hline $55-64$ & Poor & 2 & 7.14 \\
\hline $65-79$ & Average & 12 & 42,85 \\
\hline $80-89$ & Good & 7 & 25 \\
\hline $90-100$ & Very Good & 4 & 14,28 \\
\hline \multicolumn{2}{|c|}{ Total } & 28 & 100 \\
\hline
\end{tabular}

Based on Table VII above, from 28 students who were given the test, the results on Algebra Factorization shows that the mean score of students' learning outcomes through direct 
learning model is 73.82 which indicates that the students' ability in understanding the material of Algebra Factorization centered at 73.82 with a standard deviation of 12.98, which means deviation data from the average value is 12.98 . Median 76 means $50 \%$ of students obtained a score above 76 and $50 \%$ under 76 . Mode of 70 which means the most students got 70 . Because the value of mode < mean, then shaped of distribution was a positive curve means means the tendency of data gathered under the average. Furthermore, based on Table 6 and Table 7, the information is obtained that the average of learning outcomes is 73.82 of the score ideal of 100 and in an average category.

\section{The Results of Inferential Statistical Analysis Normality Tests}

Normality test aims to determine whether population is normally distributed or not. Normality test was conducted using Chi-square table. Based on the result of analysis, the students who taught by cooperative learning model Two Stay Two Stray (TSTS) was at the level of significance $\alpha=0.05$ with degrees of freedom (df) $=27$, obtained by Chi-square calculation $\left(\chi_{\text {test }}^{2}\right)=$ 7.90 and Chi-square table $\left(\chi_{\text {table }}^{2}\right)=9.48$. Because $\chi_{\text {test }}^{2}<\chi_{\text {table, means score of mathematics }}^{2}$ learning outcomes of students taught by cooperative learning model Two Stay Two Stray (TSTS) was normally distributed. Furthermore, the group who taught by direct learning model obtained by Chi-square calculation $\left(\chi_{\text {test }}^{2}\right)=6.79$ and Chi-square table $\left(\chi_{\text {table }}^{2}\right)=9.48$. Because $\chi^{2}$ test $<\chi_{\text {table, means score of mathematics learning }}^{2}$ outcomes of students taught by direct learning model was normally distributed. This is in line with the results of the analysis using SPSS as shown in Table VIII below:

TABEL VIII

TESTS OF NORMALITY

\begin{tabular}{llrlrrrrr}
\hline & & \multicolumn{3}{c}{ Kolmogorov-Smirnov $^{\text {a }}$} & \multicolumn{3}{c}{ Shapiro-Wilk } \\
\cline { 3 - 8 } & Class & Statistic & Df & Sig. & Statistic & df & \multicolumn{1}{c}{ Sig. } \\
\hline Learning & Experimental & .098 & 28 & $.200^{*}$ & .945 & 28 & .146 \\
Results & Control & .099 & 28 & $.200^{*}$ & .951 & 28 & .213 \\
\hline
\end{tabular}

a. Lilliefors Significance Correction

*. This is a lower bound of the true significance.

Source: SPSS
Based on Table VIII above, it shows that the probability value for class taught by cooperative learning model Two Stay Two Stray (TSTS) is 0.146 and for class taught by direct learning model is 0.213 . Because the probability value is greater than $\alpha=0.05$ then both of data is normally distributed.

\section{Homogeneity Tests}

Testing of homogeneity both mathematics learning outcomes data used $\mathrm{F}$ test comparing large and small variance. The aims of homogeneity test is to determine whether these two groups have the same ability or not. From these calculations obtained value of $F_{\text {test }}=1.33$ with the level significance $(\alpha)=0.05$ and $\mathrm{df}=\left(V_{1}\right.$, $\left.V_{2}\right)=(27.27)$ and obtained $F_{\text {table }}=1.90$. Because $F_{\text {test }}<F_{\text {table }}$ means that score of student learning outcomes taught using cooperative learning model Two Stay Two Stray (TSTS) and direct learning model in the eighth grade of SMP Negeri 2 Polong Bangkeng Utara, Takalar is homogeneous. This is in line with the results of the analysis using SPSS as shown in Table IX below:

TABEL IX

TEST OF HOMOGENEITY OF VARIANCES

\begin{tabular}{cccccc}
\hline Levene Statistic & & df1 & & df2 & Sig. \\
\hline & .483 & & 1 & 54 & .490 \\
\hline
\end{tabular}

Source: SPSS

Based on Table IX above, it shows that probability value is $0.490>\alpha=0.05$. It indicates that the research data have the same variance (homogeneous).

\section{The Results of Hypothesis Tests}

In Chapter II has presented the hypothesis that a temporary answer for the problem research, which are statistically defined as follows: $H_{0}: \mu_{2} \leq \mu_{1}$ opponent to $H_{1}: \mu_{2}>\mu_{1}$. To test this hypothesis used t-test by finding the standard deviation combined first.

From the calculation, it was obtained $\mathrm{t}_{\text {test }}=$ 2.195 with a significance level $\alpha=0.05$ and degrees of freedom $(\mathrm{df})=27$, obtained $\mathrm{t}_{\text {table }}=$ 1.673. Because $t_{\text {test }}<t_{\text {table }}$ namely $2.195>1.673$ then $\mathrm{H}_{0}$ is rejected and $\mathrm{H}_{1}$ is accepted. This means that the level of confidence is $95 \%$. It can be 
concluded that the mathematics learning outcomes of students taught using cooperative learning model type Two Stay Two Stray (TSTS) is higher than the mathematics learning outcomes of students taught using direct learning model.

\section{B. Discussion}

The study involved two different groups, namely the experimental group by applying cooperative learning model Two Stay Two Stray (TSTS) and the control group by applying direct learning model.

From the descriptive analysis results, it was obtained that the average of students' learning outcomes taught by cooperative learning model Two Stay Two Stray (TSTS) amounted to 80.75 with a standard deviation of 11237 and the average results of students' mathematics learning taught by direct learning model was 73,82 with a standard deviation of 12.98. This shows that the average results of studying mathematics taught by cooperative learning model Two Stay Two Stray (TSTS) is higher than the average results of studying mathematics taught by direct learning model.

Theoretically, the application of cooperative learning model Two Stay Two Stray (TSTS) allows students a variety of activities. During the learning process students are given tasks such as problems to be solved in groups. This is done in order to make students more confidence and then the students are directed to another group to get information, so that students are more oriented and liveliness. After that, the students back to their group and match the findings and then deliver the information in front of the class. This is done to make students more willing to express their opinion. Therefore, the way to teach them is by giving a chance to the students to discover and explain their opinion, creative in solving problems. This can enrich their knowledge so the achievement or students' learning outcomes can be improved well.

This is supported by the research conducted by Fitriani (2013). The results of analysis of student learning outcomes, student activities, and student response to the activities of cooperative learning type Two Stay Two Stray (TSTS) are met, the application of cooperative model of type Two Stay Two Stray (TSTS) is effective to be used in learning Algebra Factorization at the eighth grade of SMP Negeri 2 Polong Bangkeng Utara, Takalar.

Based on the result of previous research and the theory above, it can be concluded that the application of cooperative learning model Two Stay Two Stray (TSTS) can improve the learning outcomes, where the students' learning outcomes taught using cooperative learning model type Two Stay Two Stray (TSTS) is higher than the learning outcomes of students who were taught using direct learning model at the eighth grade of SMP Negeri 2 Polong Bangkeng Utara, Takalar.

\section{CONCLUSION}

Based on the data analysis and discussion of the research by using cooperative learning model type Two Stay Two Stray (TSTS) and learning by using direct learning model at the eighth grade of SMP Negeri 2 Polong Bangkeng Utara, Takalar, it can be concluded that the application of cooperative learning model Two Stay Two Stray (TSTS) positively impact on mathematics learning outcomes that can be seen as the follows:

1. The mathematics learning outcomes at the eighth grade students of SMP Negeri 2 Polong Bangkeng Utara, Takalar taught using cooperative learning model Two Stay Two Stray (TSTS) is in a good category with the mean score 80.75 and standard deviation is 11.237.

2. The mathematics learning outcomes at the eighth grade students of SMP Negeri 2 Polong Bangkeng Utara, Takalar taught using direct learning model is in average category with the mean score 73.82 and standard deviation is 12.98 .

3. The mathematics learning outcomes at the eighth grade students of SMP Negeri 2 Polong Bangkeng Utara, Takalar taught using cooperative learning model Two Stay Two Stray (TSTS) is higher than the mathematics learning outcomes taught using direct learning model. 


\section{REFERENCES}

Lie, Anita. (2007). Cooperative Learning Mempraktikkan Cooperative Learning di Ruang-Ruang Kelas. Jakarta: PT. Grasindo.

Misbahuddin dan Hasan, Iqbal. 2013. Analisis Data Penelitian dengan Statistik. Jakarta: PT Bumi Aksara.

Nurhusain, M. (2013). Peningkatan Hasil Belajar Matematika melalui Pembelajara Kooperatif tipe Two Stay Two Stray dengan Mengintensifkan Scaffolding pada Siswa Kelas VII.2 SMP Negeri 1 Bontoramba. Jurnal Panrita. Vol 8 No. 3: 266-274.

Shoimin, Aris. (2014). 68 Model Pembelajaran Inovatif dalam Kurikulum 2013. Yogyakarta: Ar-Ruzz Media.

Suprijono, Agus. (2009). Cooperatif Learning Teori \& Aplikasi PAIKEM. Yogyakarta: Pustaka Pelajar. 